\title{
PERANCANGAN TAMBAL BAN MENGGUNAKAN ELEKTRIK DI TEMBILAHAN
}

\section{SLAMET RIYADI}

Program Studi Teknik Industri ,Universitas Islam Indragiri

Jln.ProvinsiParit1Tembilahan-Indragiri Hilir-Riau

Email: slametriayadiunisi@gmail.com

\begin{abstract}
This design is a type of development design that aims to produce a media tire penampal tool that uses electrical system that is economical and practical as a business and know the feasibility of the product in the form of tire penampal that uses electrical system this tool to penampal motorcycle ynag heating using electricity does not use fire The excess of this design can be useful for the community does not pose a danger to the community and also for students to know the development of technology still play a very important role in the era of take-off as it is today, and we are demanded to be able to display a product with a decent quality and Can be accountable for the truth. Especially in small business (Home industry) government give impetus in order to improve product that yielded both in terms of quality and quantity.
\end{abstract}

Keywords: prohibition of pamphlet, quality, electrical

\begin{abstract}
Abstrak
perancangan ini merupakan jenis perancangan pengembangan yang bertujuan untuk menghasilkan media alat penampal ban yang menggunakan system elektrik yang hemat biyaya dan praktis sebagai usaha dan mengetahui kelayakan produk berupa alat penampal ban yang menggunakan system elektrik alat ini untuk penampal sepeda motor ynag pemanasnya menggunakan listrik tidak menggunakan api.kelebihan dari perancangan ini dapat berguna bagi masyarakat tidak menimbulkan bahaya bagi masyarakat dan juga agar mahasiswa dapat mengetahui perkembangan teknologi masih memegang peranan sangat penting dalam menuju era tinggal landas seperti saat ini, dan kita di tuntut agar dapat menampilkan suatu produk dengan kualitas yang layak dan dapat di pertanggung jawapkan kebenarannya. Khususnya pada pengusaha kecil (Home industri) pemerintahan memberi dorongan agar dapat meningkatkan produk yang di hasilkan baik dalam segi kualitas maupun kuantitas.
\end{abstract}

Katakunci: Tampal Ban, Kualitas, Elektri 


\section{PENDAHULUAN}

\subsection{Latar Belakang}

Teknologi masih memegang peranan penting dalam menuju ertinggal

landasseperti saat ini, dan kita dituntut agar dapat menampilkan suatu produk dengan kualitas yang layak dan dapat di pertanggung jawapkan kebenarannya. Khususnya pada pengusaha kecil (Home industri) pemerintahan memberi dorongan agar dapat dapat meningkatkan produk yang di hasilkan baik dalam segi kualitas maupun kuantitas.Sehingga Kendaraan bermotor banyak di jumpai di seluruh wilayah Nusantara.

Seiring kemajuan jaman dan perkembangan teknologi perusahaan pembuatan ban menemukan jenis ban baru yaitu ban tubles.pada umumnya masyarakat menggunakan metode press dengan panas. Energi panas tersebut bertujuan untuk merekatkan karetban sebelumnya sudah diberi lem kemudian di rekatkan pada bagian ban yang bocor. Proses pemanas tersebut menggunakan minyak tanah yang di bakar pada tungku. Pada saat ini harga minyak tanah merangkak naik cukup sulit untuk di dapat.Ini terjadi kebijakan pemerintah yang mengkonfersi minyak ke gas.Faktor itu juga yang mendorong penelitian untuk mendesain ulang agar dapat di sesuaikan dengan kondisi saat ini. Proses pemasakan memakan waktu cukup lama untuk menghasilkan tambalan yang optimal dan membutuhkan bahan bakar yang tidak sedikit untuk mempercepat pemanasan yang baik dan tidak. Apabila dibiarkan terlalu lama juga dapat menimbulkan kerusakan pada ban yang ditambal karena ban terlalu panas dan rusak.

Pada penelitian ini pres ban minya tanah digunakan sebagai bahan penelitian untuk di kembangkan atau direkondisi supaya nantinya dapat mengoptimalkan fungsi produk dan menekan waktu proses pemanasan. Pengembangkan produk diarahkan pad perubahan pada proses pemasakan atau penempelan ban pada ban, alat pemanas yang berasal dari apai akan diganti dengan pemanas listrik. Selain itu alat tersebut akan dipasang alat otomatis yang akan mati sendiri apabila mengalami panas yang cukup tinggi dan produk lambalan ban otomatis ini tidak akan menimbulkan kerusakan karena sudah di pasang kontrol pemanas yang menjaga agar tidak terjadi pemanasan yang beebihan. Produk lama akan juga mengalami pemangkasan atau penyederhana agar nantinya bisa lebih praktis dan terkesan rapid an tidak menimbulkan polusi udara karena proses pemanasannya menggunakan listrik.beberapa perubahan tersebut yang membuat produk tambal ban lisrik ini lebih baik dari pada produk sebelumnya dan di harapkan bisa dijadikan sebagai alat tepat guna yang efektif dan efesien.

Selama ini yang kita ketahui banyak nya sepeda motor yang ada di seluruh wilayah Indonesia dan banyak jugaperbengkelan yang di tepijalan kususnya penambal ban sepeda motor banyak di temui di seluruh wilayah nusantara yang ada di Indonesia. Maka dari itu bengkel penambal ban masih menggunakan alat manual dengan cara di bakar menggunakan kompor untuk membakarnya. Maka dari itu saya akan merancang alat penampal ban menggunakan system aliran listrik untuk menimbulkan energy panas untuk menghemat ekonomi dan mudah di bawa kemana-mana dan tidak menggunakanlagi dengan cara di bakar. Tujuan yang ingin dicapai dalam penelitian ini adalah memenuhi harapan atau voice of customer untuk alat yang akan dibuat. Membuat press ban elektrik yang sesuai dengan voice of customer untuk keperluan manambal ban maka dari itu saya inin menarik judul" perancangan tambal ban menggunakan elektrik"

\section{LANDASAN TEORI}

\subsection{Perancangan Produk}

Perancang produk atau desain adalah satu proses yang bertujuan untuk menganalisis,menelai memperbaiki menyusun satu sistem (fisik/non fisik)yang optimum di waktu mendatang dengan memanfaatkan informasi. Perancangan produk memiliki 
berbagai macam konsep yang dapat di aplikasikan guna menunjang pencapaian tujuan perancangan.Ciri dari aktivitas perancangan adalah bahwa selalu dimulai dari akhir berakhir di awal, artinya focus dari aktivitas perancangan adalah titik akhir (deskripsi produk).

Salah satu katateristik manusia adalah mereka selalu berusaha menciptakan suatu alat meupun benda lain untuk membantu kehidupan mereka. Guna mewujutkan benda tersebut diperlukan suatu rancangan atau desain. Menghasilkan suatu produk yang sesuai dengan kebutuhan manusia adalah hal yang ingin dicapai dari proses perancangan. Salah satu cara adalah dengan merancangan, dengan berorientasi terhadap keinginan dan kebutuhan pelanggan.

Perancangan produk berarti sudah termasuk didalamnya setiap aspek teknik dan produk, mulai dari pertukaran atau pengganti komponen dalam pembuatan, perakitan, penyelesaian (finishing), sampai pada kekurangannya (ginting, 2010).

\subsubsection{Tahapan Proses Perancangan Produk}

Produk adalah sebuah "artefa" sesuatu yang merupakan kreativitas budidaya manusia (man-made object) yang dapat dilihat, dirasakan serta diwujudkan untuk memenuhi kebutuhan fungsional tertentu yang dihasilkan melalui sebuah proses panjang. Serangkaian kegiatan yang diperlukan berupa perancangan, perancangan dan pengembangan produk, dan untuk bisa menghasilkan produk khususnya produk industry yang memilikai nilai komersial tinggi, yaitu

mulai dari tahap menggali idea atau gagasan tentang fungsi-fungsi yang dibutuhkan dan dilanjutkan dengan tahapan pengembangan konsep, perencangan.

sistem yang detail, pembuatan prototype, evaluasi dan pengujian (baik uji kelayayakan teknis maupun kelayakan komersial), dan berakhir dengan pendistribusian.

Proses perancangan maupuan pada pengambangannya, pengertian tentang produk tidaklah bisa dipandang hanya dari sekilas fisik. Ciri (attributes) ataupun unsur (ingteditens) semata (yang akan menghasilkan fungsi produk semata), melainkan harus juga dilihat, difikirkan dan dirancang kembangan komponen-komponen yang lain berupa kemasan (packaging) dan komponen pelayanan penunjang (support service component) yang akan membantu sebuah rancangan produk yang lengkap dan terintegrasi.

Aktivitas perancangan produk secara umum (genetic) akan diawali dengan tahapan identifikasi dan formulasi (mission statement) tentang segala potensi teknologi produk maupun teknologi proses, yang dimiliki serta pasar yangdi puaskan.

Penyusunan sebuah konsep poduk diperlukan, bisa berupa produk baru maupun produk lama yang aka di modifikasi menjadi sebuah produk baru yangmencoba mewujudkan ide ataupun gagasan yang masih bersifat abstraktif menjadi sebuah rancangan (system \& detail design) yang mampu memberikan gambaran menjadi lebih jelas mengenai bentuk penampilan yang di inginkan untuk memenuhi kebutukan pasar atau dilatarbelakangi oleh dorongan dan inovasi teknologi.

\section{METODOLOGI PENELITIAN 3.1 Tahap Penelitian}

Dalam melakukan penelitian ilmiah digunakan langkah-langkah yang jelas. Langkah-langkah ini akan menggambarkan tentang bagaimana susunan penelitian mulai dari awal hingga akhir sehingga rangkaian penelitian dapat dipahami secara jelas.

\subsection{Persiapan Penelitian}

pada tahap ini dilakukan identifikasijenis penelitian, dengan setudi kepustakanan yang digunakan untuk menguasai teori yang relevan dengan topik atau masalah penelitian dan rencana model rancangan, sehingga penelitian tidak terjadi duplikasi penelitian digunakan penulisan sebagai dasar pemikiran untuk membahas permasalahan yang ada. Selain itu penelitian melakukan perbandingan terhadap penelitianpenelitian dan jurnal-jurnal yang berkaitan dengan perancangan.

Studi ini dilakukan dengan membaca dan mempelajari beberapa referensi seperti literature, laporan ilmiah dan tulisan ilmiah lainnya yang dapat mendukung terbentuknya landasan teori, sehingga dapat di gunakan 
sebagai landasan yang kuat dalam analisis penelitian.

\subsubsection{Rumusan Masalah}

Perumusan masalah dalam penelitian ini adalah bagai mana merancang alat kompor penambal ban menggunakan listrik.sehingga dapat mempermudah bagi tukangbengkel sepedamotor, menghemat biaya dan tidak berpolusi.

\subsubsection{Setudi Lapangan DanLiteratur}

Setudi lapangan yang dilakukan dalam penelitian ini adalah mengetahui cara kerja, perangkat-perangkat yang diperlukan,logika yang digunakan, proseskerja dalam merancang alat, setudi literatur berfungsi sebagai penduan, sumber informasi dan data yang mengenai sebuah perancanaan dan pembuatan alat.

\subsubsection{Pengumpulan Data}

Penelitian ini membutuhkan data-data yang dikumpulkan untuk membantu dalam proses perancangan, pengumpulan di lakukan dengan menggunakan 2 jenis data antara lain:

1. Data primer
Data ini data yang langsung
diperoleh dari sumbernya melalui
pengamatan dan pencatatan
langsung.
2.
Data sekunder
Data sekunder adalah data berupa
informasi-informasi yang diperoleh
dengan mempelajari buku referensi
atau literature-literatur yang
berhubungan
objekpenelitian.

\subsection{Pengolahan Data}

Setelah penelitian menyajikan langkah diatas,selanjutnya penelitian secara khusus akan menjelaskan prihal pengolahan data. Pengolahan data berkaitan dengan beberapa uji statistic setelah data-data yang telah dikumpulkan terkumpul, maka dilakukan pengolahan data. Rumusan-rumusan yang digunakan dalam pengolahan data sebagai berikut:

\section{PENGUMPULAN DAN PENGOLAHAN DATA}

\subsection{Penemu Alat Tambal Ban Elektrik}

\subsubsection{Penemuan Pertama Alat Ban Elektik}

Alat tambal ban electric buatan Maksum Warga desa Tedunan Kecamatan Kedung Kabupaten Jepara perlahan tapi pasti pemasarannya sudah hampir merambah ke seluruh Indonesia. Meskipun hanya mengunakan cara On line namun para pembeli yang order setiap waktu terus bertambah sehingga sang membuat merasa kewalahan karena spare partnya khususnya pemanas harus pesan pada toko electric terlebih dahulu. Oleh karenanya permintaan para konsumen mundur hampir satu bulan lebih karena menunggu datangnya spare part tersebut.

Namun pada bulan Februari depan stok alat tambal ban electric akan normal kembali seiring dengan tersedianya perlengkapan peralatan untuk membuat dan juga spare partnya , sehingga pembeli yang akan membutuhkan alat tambal ban ini tidak akan menunggu lama. " Memang pada bulan Desember dan Januari kemarin stok alat tambal ban saya habis , dikarenakan menunggu spare part pemanas dari toko, selain itu kami juga membuat alat cetakan pemanas yang baru sehingga konsumen yang akan beli atau pesan alat tambal ban ini harus menunggu lama. Namun untuk ke depan kami akan membuatnya terus secara rutin karena permintaan alat tambal ban ini terus naik ", ujar Maksum di rumahnya sambil membungkus alat tambal ban electric. Alat Tambal ban electric buatan Maksum dari Jepara Penemuan alat tambal ban electric ini dipicu oleh hobynya yang senang otak-atik barang electro, selain itu disebabkan oleh naiknya bahan bakar terutama minyak tanah yang banyak digunakan untuk memanaskan peralatan tambal ban. Melihat itulah ia mencoba merancang membuat alat tambal ban listrik yang prinsipnya hampir sama dengan seterika listrik dengan model elemen pemanas ia rangkai didalam plat besi bundar. Selain itu ia buat juga badan alat tambal ban seperti model manual dengan pegangan atas yang bisa diputar, kayu penjepit ban yang dirangkai dengan pemanasnya yang disuply dengan listrik. Energi listrik yang digunakan tidaklah besar hanya sekitar 80 watt saja, waktu 
pemanasannya juga cukup singkat hanya $5-10$ menit saja, sehingga alat tambal ban ini cukup praktis digunakan dirumah atau membuka usaha tambal ban. "Alat tambal electric yang saya buat ini cukup praktis, siapapun bisa mengoperasikannya yang penting menguasai tehnik menambal ban secara manual menggunakan alat bakar secara benar.

Oleh karena itu bagi yang membuka usaha tambal ban alat ini bisa dijadikan alat tambal ban alternative. Sementara yang ingin membuka usaha tambal ban alat ini sangat cocok karena kepraktisannya namun tekhnik penambalan bannya harus dipelajari terlebih dahulu " tambah Maksum yang sehari-harinya berprofesi sebagai montir dan juga pengelasan besi.

Sementara itu Fatkhul Muin pengelola Blog Pusat Informasi Masyarakat Pesisir ( http//www.for-mass.blogspot.com yang sekaligus pemasaran secara on line mengatakan, alat tambal ban electric buatan Maksum warga Jepara ini sudah dibeli orang hampir di seluruh Indonesia. Dia pernah mengirim alat tambal ban electric ini sampai ke Medan, Pangkalan Bun , Palu , Kutai kertanegara dan Bali , untuk kota di pulau Jawa sudah hampir merata , Surabaya, Jember, Yogyakarta, Depok dan juga Bekasi. Oleh karena itu fihaknya terus berkoordinasi dengan pembuatnya agar kualitas alat tambal ban electric it uterus ditingkatkan seiring permintaan pasar yang terus ada. Fihaknya optimis jika alat tambal ban electric ini akan terus dibutuhkan orang, baik untuk kebutuhan pribadi , maupun untuk membuka usaha tambal ban yang saat ini marak dimana-mana seiring dengan pertambahan jumlah kendaraan roda dua.

Maksum membungkus alat tambal ban electric "Ya kami yakin usaha pembuatan alat tambal electric ini cukup prospektif, oleh karena itu ke depan kami akan mematenkan alat tambal ban electric ini agar kami mempunyai Hak Patennya dan penemuan kami ini tidak ditru orang lain. Namun karena kendala dana maka niat kami untuk mematenkan barang tersebut belum dapat terlaksana. Apalagi kami memfokuskan dulu ke pemasaran agar alat tambal ban ini dikenal orang diseluruh Indonesia terlebih dahulu.

\section{ANALISA}

\subsection{Analisa Alat Tambal Ban Yang Lama Menggunakan Minyak Atau Sepritus}

Pada saat belum adanya teknologi yang kita rasakan seperti saat ini khususnya pada pengusaha kecil (home industry) yaitu di bidang perbengkelan yang ada di tembilahan. Proses pemanasan tersebut menggunakan minyak tanah maupun sepritus untuk membakarnya pada tungku. Adapun pada saat ini harga minyak tanah maupun sepritus sudah meningkat cukup sulit untuk di dapat. Ini terjadi kebijakan pemerintah yang mengkongfersi minyak tanah ke gas lpg.

Pada penelitian ini pres ban minyak tanah digunakan sebagai bahan penelitian untuk di kembangkan atau direkondisi supaya nantinya dapat mengoptimalkan fungsi produk dan menekan waktu pemanasan karena alat pres tambal ban disebut juga kompor penambal ini sangan merugikan bagi pengusaha kecil yaitu perbengkelan karena pres tambal ban atau kompor juga mengakibatkan folusi bagi penambal ban, alat tambal ban yang menggunakan minyak bisa menimbulkan kerusakan pada ban yang ditambal karena ban terlalu panas dan rusak. Kekurangan-kekurangan pada alat tambal ban yang menggunakan minyak adalah sebagai berikut:

1. Dapat menimbulkan polusi/asap

2. Bisa menimbulkan kebakaran pada perbengkelan karena minyak yang sebagai bahan pembakar nya bisa tumpah.

3. Bisa meikbulka kerusakan pada ban yang di tambal karna pres atau kopor panas berlebihan mengakibatkan penampalan ban akan rusak ataupun meleleh.

4. Catra kerjanya sangat memakan waktu yang cukup lama

5. Carmenggunakan alat tambal ban yang menggunakan minyak sangat rebibet untuk menggunakan nya

\subsection{Analisa Alat Tambal Ban Yang Baru Menggunakan Tenaga Listrik Untuk Mengganti Minyak Atau Pun Sepritus}


Alat tambal ban electric buatan Maksum Warga desa Tedunan Kecamatan Kedung Kabupaten Jepara perlahan tapi pasti pemasarannya sudah hampir merambah ke seluruh Indonesia. Meskipun hanya mengunakan cara On line namun para pembeli yang order setiap waktu terus bertambah sehingga sang membuat merasa kewalahan karena spare partnya khususnya pemanas harus pesan pada toko electric terlebih dahulu. Oleh karenanya permintaan para konsumen mundur hampir satu bulan lebih karena menunggu datangnya spare part tersebut.

Namun pada bulan Februari depan stok alat tambal ban electric akan normal kembali seiring dengan tersedianya perlengkapan peralatan untuk membuat dan juga spare partnya, sehingga pembeli yang akan membutuhkan alat tambal ban ini tidak akan menunggu lama. “ Memang pada bulan Desember dan Januari kemarin stok alat tambal ban saya habis , dikarenakan menunggu spare part pemanas dari toko, selain itu kami juga membuat alat cetakan pemanas yang baru sehingga konsumen yang akan beli atau pesan alat tambal ban ini harus menunggu lama.

Namun untuk ke depan kami akan membuatnya terus secara rutin karena permintaan alat tambal ban ini terus naik ", ujar Maksum di rumahnya sambil membungkus alat tambal ban electric. Alat Tambal ban electric buatan Maksum dari Jepara Penemuan alat tambal ban electric ini dipicu oleh hobynya yang senang otak-atik barang electro, selain itu disebabkan oleh naiknya bahan bakar terutama minyak tanah yang banyak digunakan untuk memanaskan peralatan tambal ban. Melihat itulah ia mencoba merancang membuat alat tambal ban listrik yang prinsipnya hampir sama dengan seterika listrik dengan model elemen pemanas ia rangkai didalam plat besi bundar. Selain itu ia buat juga badan alat tambal ban seperti model manual dengan pegangan atas yang bisa diputar, kayu penjepit ban yang dirangkai dengan pemanasnya yang disuply dengan listrik. Energi listrik yang digunakan tidaklah besar hanya sekitar 80 watt saja, waktu pemanasannya juga cukup singkat hanya $5-10$ menit saja, sehingga alat tambal ban ini cukup praktis digunakan dirumah atau membuka usaha tambal ban. " Alat tambal electric yang saya buat ini cukup praktis, siapapun bisa mengoperasikannya yang penting menguasai tehnik menambal ban secara manual menggunakan alat bakar secara benar.

Oleh karena itu bagi yang membuka usaha tambal ban alat ini bisa dijadikan alat tambal ban alternative. Sementara yang ingin membuka usaha tambal ban alat ini sangat cocok karena kepraktisannya namun tekhnik penambalan bannya harus dipelajari terlebih dahulu " tambah Maksum yang sehari-harinya berprofesi sebagai montir dan juga pengelasan besi.

Sementara itu Fatkhul Muin pengelola Blog Pusat Informasi Masyarakat Pesisir ( http//www.for-mass.blogspot.com yang sekaligus pemasaran secara on line mengatakan, alat tambal ban electric buatan Maksum warga Jepara ini sudah dibeli orang hampir di seluruh Indonesia. Dia pernah mengirim alat tambal ban electric ini sampai ke Medan , Pangkalan Bun , Palu , Kutai kertanegara dan Bali , untuk kota di pulau Jawa sudah hampir merata, Surabaya, Jember, Yogyakarta, Depok dan juga Bekasi. Oleh karena itu fihaknya terus berkoordinasi dengan pembuatnya agar kualitas alat tambal ban electric it uterus ditingkatkan seiring permintaan pasar yang terus ada. Fihaknya optimis jika alat tambal ban electric ini akan terus dibutuhkan orang, baik untuk kebutuhan pribadi, maupun untuk membuka usaha tambal ban yang saat ini marak dimana-mana seiring dengan pertambahan jumlah kendaraan roda dua.

Maksum membungkus alat tambal ban electric "Ya kami yakin usaha pembuatan alat tambal electric ini cukup prospektif, oleh karena itu ke depan kami akan mematenkan alat tambal ban electric ini agar kami mempunyai Hak Patennya dan penemuan kami ini tidak ditru orang lain. Namun karena kendala dana maka niat kami untuk mematenkan barang tersebut belum dapat terlaksana. Apalagi kami memfokuskan dulu ke pemasaran agar alat tambal ban ini dikenal orang diseluruh Indonesia terlebih dahulu.

Berdasarkan penelitian hasil konsep perancangan alat tambal ban menggunakan listrik maka rancangan alat ini saya pilih karena memiliki unggulan pada bagian cara kerja atau cara penggunaan alat tambal ban menggunakan listrik ini lebih cepan dan praktis tinggigal ditekan tangkai penekan 
tambal ban langsung mengunci sendiri dan tidak payah lagi kita memutar untuk menekannya lagi.

Denagan pemanasan yang lebih cepat di bandingkan yang menggunakan minyak atau sepritus sebagai pembakarnya, perbandingan alat tambal ban yang menggunakan bakar minyak dengan waktu 5 menit suhu panasnya sekitar $170^{\circ} \mathrm{c}$.alat tambal ban yang menggunakan aliran listrik dalam waktu 4 menit suhu panas sekitar $200^{\circ} \mathrm{c}$ dan lebih praktis yang menggunaka alat tambal ban yang menggunakan listrik.

\section{PENUTUP}

6.1 Kesimpulan

Kesimpulan dari penelitian mengenai perbaikan rancangan alat lama yang menggunakan minyak untuk sebagai pemanasnyadan alat tambal ban yang menggunakana listrik untuk mengganti minyak sebagai pemanasnyayang ergonomis untuk menggunakannya dan simpel untuk dibawak kemana-mana.

Adapun harapan usaha bengkel yang ada di tembilahan sebagai berikut :

1. Dari hasil perbaikan rancangan tambalal ban yang dulunya yang menggunakan minyak tanah maupun sepritus untuk pemanasnya sekarang diganti dengan menggunakan listrik untuk menggantikan pemanasnya yang sangat mudah untuk menggunakan dan praktis.

2. Harapan untuk pengusaha perbengkelan yang kususnya yang ada ditembilahan untuk keinginan yaitu bisa menguntungkan bagi pengusaha perbengkelan dan membantu perekonomian pengusaha perbengkelan.

3. Besar perbedaannya dapat menghemat waktu saat kita untuk bekerja.

\section{REFERENSI}

Kunto, suharismi, 2010. Prosedurpeneitian suatu pendekatan praktek, Jakarta: perbit Rineka Cipta.

Ginting, R. 2010.Perancangan produk, Yogyakarta: Graham Ilmu.

Mahdi, 2013, Uji Normalisasi Data.https://mahdi47.files.Wordpress.co $\mathrm{m} / 2013 / 06 /$ normalitas.docx. (diakses tanggal 29 maret 2017).

Mr.daniels.2008. uji kecukupan dan keseragaman data.https://mrdaniels.files.files.Wordpres s.com/2008/10/pengujianhasilsimulasi02.pdf. (diases tanggal 29 maret 2017).

Ulrich. K.T. den Eppinger,S.D. 2001, Perancangan dan pengembanganProduksi.Jakarta: Salemba Teknikal.

Uma Sekaran, 2006, Metedologi penelitian untuk bisnis, edisi 4, buku 2, Jakarta: Salemba Empat. 